portée à l'organisation sociale et à la mythologie afin de compléter la documentation existante en vue de la préparation d'un volume du Survey dirigé par l'International African Institute. Il est prévu, d'autre part, d'établir une classification des différents groupes de populations tchadiennes pour la réalisation d'autres volumes du Survey, de manière à englober l'ensemble des peuples de la contrée.

Dans le Nord-Cameroun, la mission étudiera principalement l'habitation chez les Fali, montagnards fétichistes établis au Nord de la Bénoué, et ses rapports avec les types de construction dans les populations voisines ou apparentées.

Au Tchad comme dans le Cameroun Septentrional, ces recherches feront une large place à l'évolution actuelle des populations tant dans leurs activités matérielles que dans leurs institutions et leur comportement, suivant le programme sociologique dont une application précédente avait conduit à l'étude générale des milieux urbains de la Fédération (Mission sociologique du Haut Commissariat en Afrique Equatoriale Française) et à propos de laquelle deux rapports sont publiés ou en cours de publication (Fort-Lamy, Bangui).

\title{
African Study Centre at Northwestern University, Illinois.
}

THE Carnegie Corporation of New York has made a grant to Northwestern University, Illinois, for the establishment at the University of an African Study Centre, which will encourage and undertake African research, maintain a library, train personnel, act as a clearing house of information on Africa, and help to co-ordinate research activities in the field. Residential Fellowships and supplementary grants for fieldwork in Africa will be awarded.

The centre will be directed by Dr. Melville Herskovits, Professor of Anthropology at the University, who has carried out considerable field studies in West Africa and elsewhere, and is a member of the Executive Council of the International African Institute. Under his direction, African studies have been actively pursued at Northwestern University for a number of years. A committee consisting of members of other departments at the University will assist Dr. Herskovits.

\section{Office de la recherche scientifique Outre-Mer}

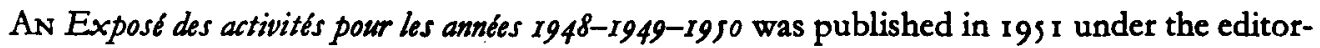
ship of M. R. Combes, Director of O.R.S.O.M. An introductory section gives an account of the history and constitution of the O.R.S.O.M., which was founded in order to co-ordinate the various research organizations operating in different centres in the French oversea territories, to create additional centres of research, to establish scientific councils, and to organize the training of research workers in many different branches of science. The other sections of the Expose describe the activities of research centres in the different territories, where the researches pursued are concerned with almost every branch of science-botany, entomology, soil conservation, hydrology, sociology, linguistics, \&c. The local centres provide facilities for study for scholars and research students from France and from neighbouring British territories; they have undertaken specific studies at the request of official and commercial organizations in the territories, and their officers have been consulted on many problems arising from the economic and industrial development of the French oversea territories. A final section describes the activities of O.R.S.O.M. in France: training of research workers, documentation, laboratory studies, publication. The concluding chapter summarizes the multifarious activities of the Office in the many different spheres with which it is concerned.

' On voit comme est multiple et variée l'activité de l'Office de la recherche scientifique Outre-Mer. S'appliquant, dans l'espace, à des territoires très divers, elle a aussi divers 
caractères, puisqu'il ne s'agit pas seulement de créer, dans les milieux métropolitains, un courant d'intérêt scientifique vers les problèmes tropicaux, mais de doter les pays d'OutreMer d'une organisation complète entièrement mise à leur service.'

\section{Blackfriars: Special number}

Blackfriars, the organ of the English Dominicans at Oxford, devotes its Jan. 1952 number to Africa. This contains a number of articles of unusual interest including a short article by Archbishop Mathew, Apostolic Delegate to British East and West Africa, an account of education in British East Africa by a missionary of the White Fathers, a discussion of some African christian sects, by R. G. Lienhardt and an article on tribal art, by W. Fagg of the British Museum.

Blackfriars is a monthly review and may be ordered from The Manager, Blackfriars Publications, 34 Bloomsbury Street, London, W.C.r.

\section{ETHNOGRAPHIC SURVEY OF AFRICA}

The following sections of the Survey are now available:

The Akan and Ga-Adangme Peoples of the Gold Coast

The Peoples of Sierra Leone Protectorate

The Ibo and Ibibio-speaking Peoples of South-Eastern Nigeria

The Yoruba-speaking Peoples of South-Western Nigeria

Peoples of the Lake Nyasa Region

Bemba and Related Peoples of Northern Rhodesia

The Southern Lunda and Related Peoples

Tribes of the Northern Territories of the Gold Coast

\section{In the Press}

The Coastal Tribes of the North-Eastern Bantu The Nilotic Peoples of the Anglo-Egyptian Sudan

All information about these, and other sections in preparation, may be obtained from the Secretary, International African Institute, who will be pleased to receive standing orders to supply copies of all secrions as they appear. 